\title{
EVALUATION OF THE EFFECT OF SORGHUM-LEGUME INTERCROPPING AND ITS RESIDUAL EFFECT ON YIELD OF SORGHUM IN YEKI WOREDA, SHEKA ZONE, ETHIOPIA
}

\author{
A. Gebremichael ${ }^{*}$, B. Bekele ${ }^{2}$ and B. Tadesse ${ }^{1}$
}

Received 4 September 2019, Revised 13 December 2019, Accepted 24 December 2019, Published online 31 December 2019

\begin{abstract}
The imbalance between the crop production and population growth is currently the major issue in southern Ethiopia. To feed the growing population, increasing the production of food through growing more crop types in the same field as an intercropping is the right strategy. The current study was aimed at evaluating the effect of sorghum-legume intercropping and its residual effect on yield of sorghum. The land equivalent ratio was calculated for sorghum intercropped with pigeon pea and cowpea. Intercropping sorghum with pigeon pea and cowpea increases the land productivity as its Land Equivalent Ratio is greater than 1. In both cases, the land equivalent ratio is greater than 1 indicating the benefits of intercropping. The residual effect of sorghum intercrop with legumes was evaluated on the yield of sorghum. Although there was no statistically significance differences on yield and yield component of sorghum, sorghum planted on the plot of pigeon pea and cowpea sole has $44.6 \%$ and $27.8 \%$ yield advantage relative to sorghum alone respectively. Planting sorghum under sorghum-cowpea intercropped condition increase the yield of sorghum by $41.8 \%$. The result also shows $74.0 \%$ sorghum yield change was observed when planted after intercropped condition of sorghum with pigeon pea. The productivity of sorghum also increases when planted on the plot of sole legume. The current finding in general shows that legume crops contributed to the yield of sorghum either intercropped with legume or grown up using residual contribution of legumes after a year. Therefore, for maximum sorghum production farmers in the area should plant either as intercrop or after residual effect of legumes.
\end{abstract}

Keywords: Intercropping, Sorghum, LER, Cowpea, Pigeon pea.

\footnotetext{
${ }^{1}$ Southern Agricultural Research Institute (SARI), Bonga Agricultural Research Centre, Bonga, Ethiopia.

${ }^{2}$ Southern Agricultural Research Institute (SARI), WorabeAgricultural Research Centre, Worabe, Ethiopia.

*Corresponding author's email: gebreabay1984@gmail.com (A. Gebremichael)
}

Cite this article as: Gebremichael, A., Bekele, B. and Tadesse, B. 2019. Evaluation of the effect of sorghumlegume intercropping and its residual effect on yield of sorghum in yekiworeda, sheka zone, Ethiopia. Int. J. Agril. Res. Innov. Tech. 9(2): 62-66. DOI: 10.3329/ijarit.v9i2.45412.

\section{Introduction}

In increasing population with limited land holding, land degradation resulting from soil erosion and fertility depletion is one of the most challenging environmental problems in Ethiopia. Smallholder farmers in highlands of Ethiopian have been experiencing declining soil fertility and severe soil erosion due to intensive farming on steep and fragile land and cultivating without soil conservation structure (Amsalu and de Graaff, 2006). The farmers were practically very resistant to implement physical soil and water conservation practices considering that it needs labor; compete for farmland and it damages the crop when destructed (Azene, 1997). This problem is nowadays being solved by application of the principle of conservation agriculture which need very minimum input cost while sustaining soil fertility and reducing erosion (Arslan et al., 2014). These methods are mostly applicable for smallholder farmers than intensification agriculture. The methods used were intercropping, green manuring, alley cropping, crop rotation, minimum or zero tillage and leaving crop residue on the farm than burning. Intercropping is mixing cropping of two or more crop (mostly legumes with non-legumes) sown simultaneously to encourage sustainability in agriculture through increasing plant diversity (biodiversity) and reducing soil fertility decline. Cereal-legume cropping system show considerable promise in boosting productivity, helping reverse the decline in soil fertility (Dagne et al., 2012). 
It can be justified that the farmers cultivate their land without soil and water conservation measures for continues long years resulting to highly degraded soil. They are also reluctant to apply artificial fertilizers due to its high cost, which resulted to very less production of sorghum yield in the area. Therefore, it is very crucial to create awareness through demonstrative research to farmers that they could use organic farming by hedge planting of nitrogen fixing multipurpose grasses/shrubs/trees on their land for sustaining land productivity. As intercropping is an important aspect of smallholder-farmer crop production systems, a study was initiated to evaluate the performance of pigeon pea and cowpea forages as an intercropping legume with sorghum and to know also their residual effect for next cropping season. Therefore, the objective of the study was to evaluate the effect of legume intercropping with sorghum on land yield of sorghum.

\section{Materials and Methods}

\section{Description of study area}

The study was conducted in Yeki District of Sheka zone in Southern Nations Nationalities and
Peoples Region (SNNPRs). Sheka zone is bordered on the south by Bench Maji, on the west by the Gambela Region, on the north by the Oromia Region, and on the east by Kefa. It lies between $7^{\circ} 24^{\prime \prime}$ to $7^{\circ} 52^{\prime \prime} \mathrm{N}, 35^{\circ} 13^{\prime \prime}$ to $35^{\circ} 35^{\prime \prime} \mathrm{E}$ and 900 to 2700 masl. The zone covers about $2175.25 \mathrm{~km}^{2}$, out of which $47 \%$ is covered by forest, and 56,24 and $20 \%$ is a highland, a mid altitude and lowland, respectively. It receives high amounts of rainfall, with an average between 1800 to $2200 \mathrm{~mm}$ per annum. The major crops grown in the zone are maize, sorghum, millet, beans, coffee, ginger, turmeric, enset, wheat, barley and pea. The zone is divided into three administrative woredas (districts), namely Yeki, Anderacha and Masha. The study area, Yekiwreda, is under sub humid weyinadega agroecology and it has elevation from 1400-180omasl with average annual rainfall of $1898 \mathrm{~mm}$ and average minimum and maximum temperature of $12^{\circ} \mathrm{C}$ and $26^{\circ} \mathrm{C}$, respectively. It is known by undulating farmland with high problem of soil erosion and declined fertility for production of sorghum, which was used for consumption and cash (Getachew et al., 2018).

\section{Location}

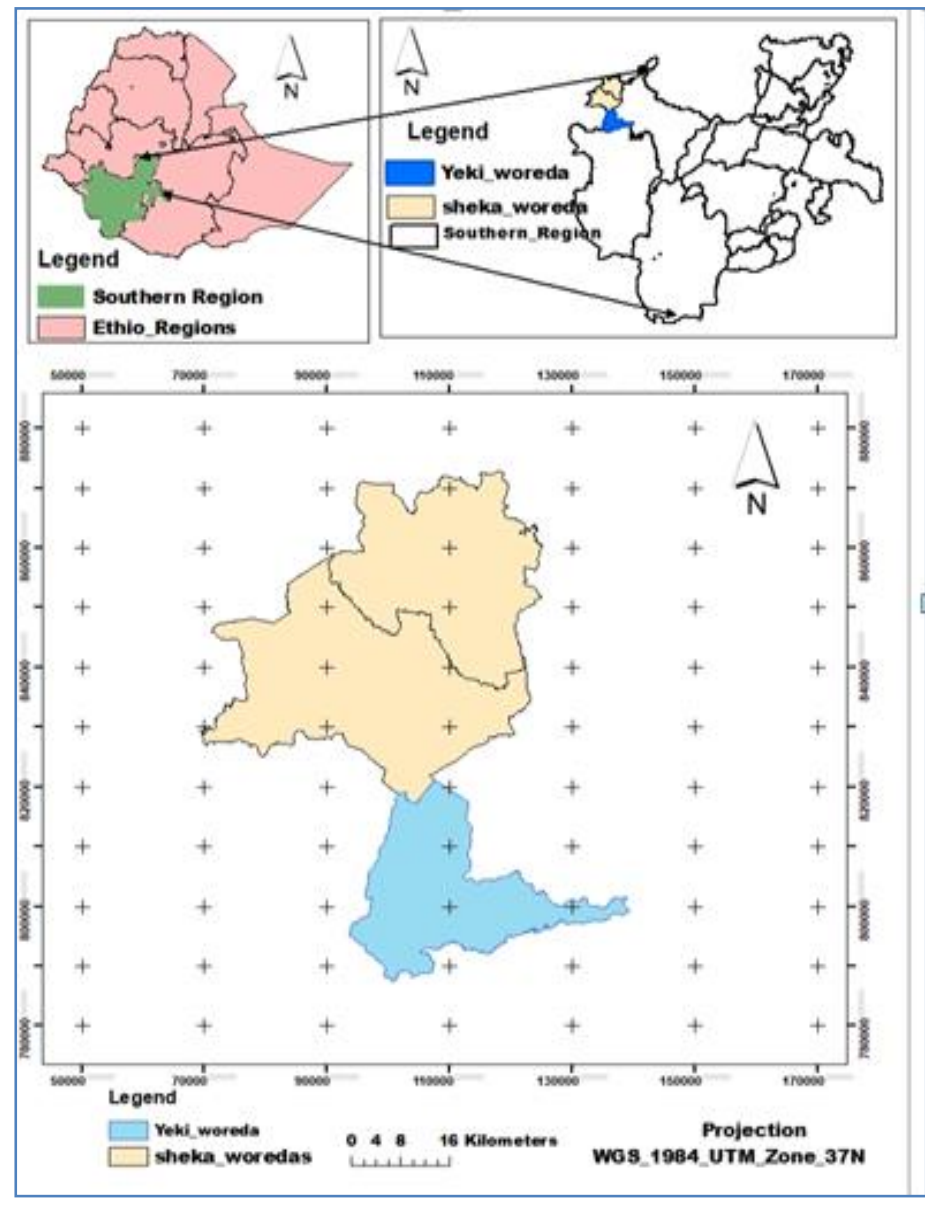

Fig. 1. Map of study area. 


\section{Treatments at first year}

$\mathrm{T} 1=$ Sorghum alone

$\mathrm{T} 2$ = Pigeon pea alone

$\mathrm{T}_{3}=$ Cowpea alone

$\mathrm{T} 4$ = Sorghum + Pigeon pea (Cajanus cajun)

$\mathrm{T}_{5}=$ Sorghum + Cowpea (Vigna unguiculata $\mathrm{L}$. )

\section{Treatments at second year}

$\mathrm{T} 1$ = Sorghum alone on plot of Sorghum

T2 $=$ Sorghum alone on plot of Pigeon pea alone

$\mathrm{T}_{3}=$ Sorghum alone on plot of Cowpea alone

$\mathrm{T} 4=$ Sorghum alone on plot of Sorghum + Pigeon pea

$\mathrm{T}_{5}=$ Sorghum alone on plot of Sorghum + Cowpea

Note: No fertilizer was applied on all plots at second year

\section{Site selection and experimentation}

Three farmers' fields were selected for conducting the research. The size of plot for the first year activity was $12 \mathrm{~m}$ wide and $12 \mathrm{~m}$ long and one farmer will host five treatments. Between plots the spacing was $1.5 \mathrm{~m}$ to prevent the effect of mixing. The sorghum was planted in rows of $30 \mathrm{~cm}$ spacing and while $40 \mathrm{~cm}$ was left between rows of sorghum and nitrogen fixing legume. The arrangement was in alternative way to sorghum and the legume (1:1). Initial application of fertilizer (half of recommended amount of N) was done during planting but the plots were maintained for next year to know its residual effect on yield by cultivating without any fertilizer application in the season. The nitrogen fixing legume was planted in $10 \mathrm{~cm}$ spacing with two seed in a single hole, one of which was avoided after emergency checking. The $10 \mathrm{~cm}$ is due to consideration of the need of biomass for the intercropped sorghum. Finally, all the residue of crops (sorghum and legume will remain on the plots for next cultivation season which will be the basic indicator of the residual effect of the legume relative to fertilizer application). The design was RCBD with 5 treatments and three replications.

\section{Data collection}

Agronomic data werecollected for days of germination, plant height, biomass (straw weight), 1000 seed weight and yield. Land equivalent ratio of intercropping system was also determined

\section{Data analysis}

The data was analyzed using SAS statistical software while Land Equivalent Ration was calculated using the following equation (Willey and Osiru, 1972):

$L E R=\frac{Y S_{\text {int }}}{Y S_{\text {Sol }}}+\frac{Y L_{\text {int }}}{Y L_{\text {sol }}}$

Where;

- YSint = Yield of sorghum under intercropping conditions

- YSsol = Yield of sorghum under sole crop conditions

- YLint = Yield of legume under intercropping conditions

- YLsol = Yield of legume under sole crop conditions

\section{Results and Discussion}

\section{Effect of sorghum-legume and its intercrop on sorghum yield}

Table 1.First year land equivalent ratio for the effect of intercropping sorghum with legume.

\begin{tabular}{|lccc|}
\hline Treatment & Sorghum yield $\left(\mathrm{kg} \mathrm{ha}^{-1}\right)$ & Legume yield $\left(\mathrm{kg} \mathrm{ha}^{-1}\right)$ & LER \\
\hline Sorghum alone & 2379.62 & 574.06 & \\
\hline Pigeon pea alone & & 909.71 & \\
\hline Cowpea alone & & 135.18 & 0.9 \\
\hline Sorghum with pigeon pea & 1592.59 & 430.55 & 1.25 \\
\hline Sorghum with cowpea & 1879.62 & \\
\hline
\end{tabular}

NB: LER-Land Equivalent Ratio

The effect of intercropping sorghum legume and its residual effect on sorghum yield and yield components was evaluated for two years period. Land equivalent ratio was used to evaluate the intercrop efficiency in yield relative to the monocropped condition. From the analysis I the table1 above, and equivalent ratio (LER) of sorghum intercropped with pigeon pea and cowpea was greater than 1 . The calculated LER for the grain yield of sorghum and pigeon pea was 0.9 while LER for sorghum with cowpea was 1.25 , which was higher than1, which indicated the benefits of intercropping. According to the finding of Izaurralde et al. (1994), the LER value greater than 1 implies more efficient utilization of land by intercrops as compared to growing monocrop in the farms. In addition, intercropping favors the growth and yield of the crops reducing weed distribution, paste and disease. In contrast, the lower value of LER below 1 indicates intercropping negatively affects the growth and yield of a crop grown. The highest 
LER was obtained from intercropping sorghum with cowpea. So, intercropping showed an advantage over sole cropping in the trail season. The higher yield under mono-cropped condition is directly related with lack of competition for nutrient and moisture. However, the lower yield under intercropped condition as compared to mono-cropped could be due to the differences in the intercropped condition particularly on growth factors and different crop species, which could better utilize nutrients from soils, compared mono cropped condition (Willey, 1985).

\section{Residual effect of intercropping sorghum-legume on yield of sorghum}

Table 2. Residual effect of intercropping sorghum-leguminous on yield and yield component of sorghum.

\begin{tabular}{|c|c|c|c|c|}
\hline Treatments & $\mathrm{Ph}(\mathrm{cm})$ & St.w (kg) & S.w $(g)$ & $\begin{array}{c}\text { Gyld } \\
\left(\mathrm{kg} \mathrm{ha}^{-1}\right)\end{array}$ \\
\hline Plot of Sorghum alone & $226.20 \mathrm{a}$ & $1.15 \mathrm{a}$ & $21.95 \mathrm{a}$ & $1995^{a}$ \\
\hline Plot of Sorghum at Pigeon pea alone & $259.20 \mathrm{a}$ & $1.30 \mathrm{a}$ & $21.40 \mathrm{a}$ & $2885 a$ \\
\hline Plot of Sorghum at Cowpea alone & $228.40 a$ & $1.30 \mathrm{a}$ & $21.50 \mathrm{a}$ & $2550 a$ \\
\hline $\begin{array}{l}\text { Plot of Sorghum at Sorghum with pigeon } \\
\text { pea }\end{array}$ & $227.60 a$ & $1.00 \mathrm{a}$ & 21.10a & $2770 a$ \\
\hline Plot of Sorghum at Sorghum with cowpea & 228.30a & $1.45 \mathrm{a}$ & $22.15 \mathrm{a}$ & $2665 \mathrm{a}$ \\
\hline Mean & 233.94 & 1.24 & 21.62 & 2573 \\
\hline CV\% & 17.62 & 21.82 & 5.07 & 30.36 \\
\hline LCD (0.05) & 95.08 & 0.62 & 2.53 & 1800 \\
\hline
\end{tabular}

Gyld-Grain yield, Sw-Seed weight, St.w-Straw weight and Ph- plant height

The intercropping of legume on cereals particularly sorghum may accrue some selected nutrients particularly Nitrogen to the soil which in turns to improve the soil fertility to benefit the subsequent crops. In the first year, all combination of sorghum with leguminous shrubs was evaluated at farm level. In second year, considering the residual advantage of leguminous shrubs to soil fertility, only sorghum as a test crop was evaluated with respect to yield and yield components after planting in the plot of pigeon pea, cowpea and under intercropped condition with legume. From statistical point of view, the grain yield and yield component was not significant $(\mathrm{p}>0.05)$ at significant level. In the first year, as shown in the table2 above, the yield of sorghum planted sole was $2379 \mathrm{~kg} \mathrm{ha}^{-1}$, intercropped with pigeon pea $1592 \mathrm{~kg} \mathrm{ha}^{-1}$ and intercropped with cowpea as $1879 \mathrm{~kg} \mathrm{ha}^{-1}$. Whereas, in the second year, the yield of sorghum planted sole was observed to be $1995 \mathrm{~kg} \mathrm{ha}^{-1}$, $2880 \mathrm{~kg} \mathrm{ha}^{-1}$ planted on the plot of pigeon pea sole, $2550 \mathrm{~kg} \mathrm{ha}^{-1}$ planted on the plot of cowpea sole, $2770 \mathrm{~kg} \mathrm{ha}^{-1}$ planted with intercrop of sorghum with pigeon pea and $2665 \mathrm{~kg} \mathrm{ha}^{-1}$ planted with sorghum with cowpea. The yield of sorghum increased from $1592 \mathrm{~kg} \mathrm{ha}^{-1}$ to $2770 \mathrm{~kg}$ ha $^{-1}$ when planted on the plot of sorghum with pigeon pea. Similarly, the yield of sorghum shows increasing trends from $1878 \mathrm{~kg} \mathrm{ha}^{-1}$ to $2665 \mathrm{~kg} \mathrm{ha}$ 1 when planted on the plot of sorghum with cowpea. The increasing trend of sorghum yield planted after leguminous intercropping could be due to the residual effect of legumes to the soil. According to Carsky et al. (2001), cereal yield are usually higher after a cowpea crop than after a cereal crop.
The result depicted that $74.0 \%$ sorghum yield change was observed when planted under intercropped condition of sorghum with pigeon pea. It also observed that, planting sorghum under sorghum-cowpea intercropped condition maximize the yield of sorghum by $41.8 \%$. However, the yield of sorghum planted under sole condition in both years decreased from $2379 \mathrm{~kg}$ $\mathrm{ha}^{-1}$ to $1995 \mathrm{~kg} \mathrm{ha}^{-1}$. The current finding shows legume crops contributed to the yield of sorghum either intercropped with legume or grown after legumes as a sole crop. The study of $\mathrm{Pal}$ and Sheshu (2001) reported the direct and residual contribution of legumes to the yield and $\mathrm{N}$ up take of maize and found that all the legume crops contributed to the yield of maize.

\section{Conclusion and Recommendation}

The imbalance between the crop production and population growth is currently the major issue in southern Ethiopia. The major constraints for declining crop yield soil erosion by water, disease, and pest, low soil moisture content due to erratic rainfall distribution, small land holding size, growing interest of farmers and lack of balanced fertilization. Growing more than one crop type in the same piece of land as an intercropping is the right strategies to harness weed distribution, prevent pest and disease, improve soil moisture and improve soil fertility through addition of nitrogen fertilizer to the soil. The current finding shows legume crops contributed to the yield of sorghum either intercropped with legume or grown after legumes as a sole crop. 
The land equivalent ratio (LER) as land productivity parameters for land use efficiency was calculated for sorghum intercropped with pigeon pea and cowpea. Intercropping sorghum cowpea increases the land productivity (LER $>1$ ) indicating the benefits of intercropping.

The residual effect of sorghum intercrop with legumes was evaluated on the yield of sorghum. Although there was no statistically significance differences on yield and yield component of sorghum, sorghum planted on the plot of pigeon pea and cowpea alone has $44.6 \%$ and $27.8 \%$ yield advantage relative to sorghum alone respectively. Planting sorghum under sorghum-cowpea intercropped condition increase the yield of sorghum by $41.8 \%$. The result also shows $74.0 \%$ sorghum yield change was observed when planted after intercropped condition of sorghum with pigeon pea. The productivity of sorghum could increases when planted on the land is treated with legume crops. Therefore, for maximum sorghum production farmers in the area should plant sorghum either as intercrop with cowpea or after residual effect of legumes specially cowpea.

\section{References}

Amsalu, A. and de Graaff, J. 2006. Determinants of adoption and continued use of stone terraces for soil and water conservation in the Ethiopian highland watershed. Ecol. Econ. 61: 294-302. DOI: 10.1016/j.ecolecon.2006.01.014.

Arslan, A., McCarthy, N., Lipper, L., Asfawa, S. and Cattaneoa, A. 2014. Adoption and intensity of adoption of conservation farming practices in Zambia. Agric. Eco. Env. 187: 72-86.

Azene, B. 1997. A Participatory Agro forestry Approach for Soil and Water Conservation in Ethiopia. Tropical Resource Management Papers, No. 17, Wageningen Agricultural University: Wageningen. 229p.
Carsky, R.J., Singh, B.B. and Oyewole, B. 2001. Contribution of early-season cowpea to late season maize in the savannah zone of West Africa. Biol. Agric. Hort. 18: 303-315.

Dagne, W., Abaya, T., Solomon, A., Solomon, J., Alemu, T., Leggesse, H., Fekadu G., Gezehagn, B., Temesgen, C. and Mulugeta, M. 2012. Towards sustainable intensification of maize-legume cropping systems in Ethiopia. pp. 120-125. In: Mosisa et al. (eds). Meeting the challenges of global climate change and food security through the innovative maize research. Proceedings of the third national maize workshop of Ethiopia, Addis Ababa, Ethiopia.

Getachew, M., Mitiku, W. and Gtahun, K. 2018. Assessment of Weed Flora Composition in Arable Fields of Bench Maji, Keffa and Sheka Zones, South West Ethiopia. Agril. Res. Tech. Open Access J. 14(1): 555906. DOI: 10.19080/ARTOAJ.2018.14.555906.

Izaurralde, R.C., Chanasyk, D.S. and Juma, N.G. 1994. Soil water under conventional and alternative cropping systems in cryoboreal sub-humid Central Alberta. Canadian J. Soil Sci. 74: 85-92.

Pal, U.R. and Sheshu, Y. 2001. Direct and Residual Contributions of Symbiotic Nitrogen Fixation by Legumes to the Yield and Nitrogen Uptake of Maize (Zea mays L.) in the Nigerian Savannah. J. Agron. Crop Sci. 187(1): 53-87. DOI: $10.1046 /$ j.1439037X.2001.00482.X

Willey, R.W. 1985. Evaluation and presentation of intercropping advantages. Exptl. Agric. 2: 119-133.

Willey, R.W. and Osiru, D.S.O. 1972. Studies on mixtures of maize and beans (Phaseolis vulgaris) with particular reference to plant population. J. Agric. Sci. Cambridge. 79: 519-529. 